\title{
Pragmatic Reference in Elvis Gbanabom Hallowell's The Dining Table
}

\author{
Olusegun Oladele Jegede \\ Department of English and Literary Studies \\ Lead City University, Ibadan, Nigeria \\ E-Mail: jegedeolusegun@yahoo.com \\ *(Corresponding Author) \\ DOI: https://doi.org/10.1836/jopr.v2i1.41-49
}

Submission
Track:
Received:
-01-02-2020
Final Revision:
03-04-2020
Available online:
06-04-2020
Corresponding
Author:
Olusegun Oladele Jegede
jegedeolusegun@yahoo.com

\begin{abstract}
This study examined the pragmatic references used in Elvis Gbanabom Hallowell's poem, The Dining Table. The study adopted content analysis as its method. This involved the description and interpretation of referents (words used to refer to people, things and events in a special and indirect way) used in the poem. The poem was critically read and the referents were identified and analysed. The referents were then interpreted and related to the ideologies expressed in the poem. The findings revealed that the poet used referents to point accusing finger to the events of war and the troubles that come with it. This was evident in the deployment of referents such as dinner, tonight, gun wounds, desert tongues, vegetable blood, pepper, scorpions, guests, oceans of bowls, vegetables, tongues, the table, an island, guerrillas, crocodiles, surf, Alphabeta, empty palms, switchblades, silence, voices, playground, children's toys, roadblocks, cup of life, ticks, cracked lips, milk, moon, revolutionary, Nile, tributaries, night, lovers of fire, gun wounds, boots, walk. The study concluded that the use of referents in the poem helped to express the brutality and horror of war, suffering, agony, revolution, the dark side of child soldiers, violence and blood bath. Above all, pragmatic reference helped to set the gloomy mood and sad tone of the poem.
\end{abstract}

Keywords: Pragmatic Reference, Referent, Pragmatics, Meaning 


\section{INTRODUCTION}

Studies in pragmatics have shown that pragmatics deals with the study of meaning in context (Jegede and Osoba, 2019; Wangatiah, Ongarora, \& Matu, 2016; Odebunmi, 2006; Odebunmi, 2008; Idowu, 2005; Aremu, 2015; Li, 2016). Karin (2013) observes that pragmatics gives preference to language use. This has to do with language in actual speech situations used for certain reasons. They are less meaningful outside speech situations. Thus, what is important is how language users use referents (what is being refered to) to communicate in oral conversations or in writing to achieve their communicative goals. The context of the speech is also of great importance in pragmatics (Gisle and Karin, 2011; Anne and Schneider, 2009; Grundy, 2000). This involves the physical location of participants in a conversation, the time of the conversation, the language of communication, the socio-cultural setting, the psychological state of the interlocutors, and the institution of discussion. These features of context are very important to our use and understanding of referents. They help us interpret referents and apply them to our text or speech. The goal of utterance or speaker's intention, is very important to the interpretation of referents as well. Referents are products of the goals of utterances or speaker intention (Horn \& Ward, 2006). In other words, what a speaker wants to achieve with a particular utterance will determine the kinds of referents he will choose. In interpreting referents, shared knowledge, culture, or conventions of participants in communication is very important.

The participants must both have a good knowledge of the referents; they must be from the same cultural background and share the same life style. Thus, our knowledge of pragmatics is very important to our interpretation and understanding of referents. This study thus examines the pragmatic references used in Elvis Gbanabom Hallowell's poem, The Dining Table. The referents are identified and interpreted and discussed based on their context of use in the poem

Studies in pragmatics have revealed that we rely on context when we speak or write, especially when we make reference to something or we talk about things (Aboh and Uduk, 2016; Emike, 2015; John, 2013, 2014; Barbara, 2000; Hidayat, 2016). One fundamental feature of human language is that we are able to talk about things we can see in our immediate environment or things that are abstract or imaginable (Ariel, 2008). The essence of human language is the way utterances relate to things or facts around us (Sullivan, 2012; Yule, 2002). However, this assertion cannot be said to be true or false because it is not every linguistic sign that has a corresponding object in the real world (Carlson, 2006). Verbs or prepositions which indicate doings and states do not have direct references. Words or phrases that usually depict references are demonstratives and indexical words (Grundy, 2000). Wangatiah, Ongarora \& Matu (2016) observe that speakers and writers often use 
one thing to refer to another thing and expect their listeners and readers to make a relationship between the two things. In some instances, some references do not actually refer to anything or anyone at all even though they are meaningful when examined semantically (Odebunmi, 2006, 2008). For instance, if you say, 'I like the tall man,' you may be referring to a specific tall man on the one hand or an unspecified tall man on the other hand, but semantically there is no specific person mentioned because there are numerous tall men in the world.

Mey (2001) explains the philosophy of reference thus:

Let's suppose I'm in a foreign country, sitting in my hotel room at night. There is a knock at the door. I didn't open the door, but asked: 'Who's there?' The visitor answers: 'It's me.' Now, what do I do? Basically, there are two possibilities. Either I recognize the visitor's voice, and then I can decide whether or not to open the door. Or I don't, and then I'm in a quandary. What can I do with a voice that refers to a 'me', when I don't know who that 'me' is? Since a 'me' always refers to an 'I', and every 'I' is a 'speaking me', the utterance 'It's me,' is always and necessarily true, and hence totally uninformative, when it comes to establishing a speaker's identity. In more technical terms, there is no known referent for 'me' by virtue of the linguistic expression me itself: of the referent of a 'deictic' word such as 'me' changes with the person uttering it.

Mey (2001) also notes that:

'I can say: 'Me who?', or 'Who's talking?', or simply repeat my first utterance ('Who's there?'), maybe in an irritated tone, or with increased volume. Depending on the answer I get, I then decide what to do. If the other person says: 'It's a friend,' I probably will want to know more, as the reference of the indefinite article 'a' is, by definition, left undetermined. If the person says: 'It's Natasha's mother,' and Natasha happens to be the name of one of my important contacts, I probably will open the door, especially if I have the additional information available that comes from (possibly) recognizing Natasha's mother by her voice.

Everybody can say $I$, and whoever says it, points to another object than everybody else; one needs as many proper names as there are speakers, in order to map (in the same way as in the case of the 
nouns) the inter-subjective ambiguity of this one ward into the unambiguous reference of linguistic symbols.

Birner (2013) observes that one of the most prominent issues in the field of pragmatics is that of reference - the question of what it is that a speaker is speaking of when they use an expression that, broadly speaking, picks out some entity. This issue comprises a vast number of sub-issues concerning referents within various possible worlds. He notes that a referring expression is a linguistic expression that a speaker uses in order to enable an addressee to 'pick out' something in the world. This is the sort of definition that is frequently given, but it already raises questions. What does it mean to pick something out? And what counts as the world? In the mentalist view, what is picked out is limited to entities in the discourse model, rather than anything in the "actual" world of concrete objects. And the question of what it means to pick out something brings up a morass of issues concerning what it is to know something's identity, what constitutes a "thing" at all, and how we know when two things are the same. Birner (2013) notes that a referring expression is a linguistic form that the speaker uses with the intention that it correspond to some discourse entity and bring that discourse entity to mind for the addressee. A referring expression, then, is a linguistic expression that a speaker uses in referring to something. The thing referred to is called the referent. Susan, Stein and Virtanen (2013) note that in a mentalist framework, the referent is a discourse entity - something that exists within a discourse model, which in turn exists only within the minds of interlocutors. In a referential framework, on the other hand, the referent is an entity in the real world.

\section{METHODS}

The study is a qualitative research. It adopted content analysis as its design. This involves the description and interpretation of referents (certain words used to refer to people, things and events in a special and indirect way) in Elvis Gbanabom Hallowell's poem, 'The Dining Table'. Although there are many poems with special referents, 'The Dining Table' is made up of a lot of referents such that virtually every word in the poem has a special usage. The poem was critically perused and the referents were identified and analysed. The referents were then interpreted and related to the ideologies expressed in the poem.

\section{RESULTS AND DISCUSSION}

The poem, The Dining Table, is a narrative poem in which the poet explains the painful ordeal of his people during the eleven-year Sierra Leonean war. As a free verse, the poem made it possible for the 
poet to pour out his experience poetically as he experienced it adopting special referents to disseminate his messages. The experiences in the poem are recollected from the events of the war that occurred in Sierra Leone years back. The poem is all about war, its pain, and suffering as well as the cause of the war. Hence, the poet deploys pragmatic reference to present his thoughts. He uses certain words (referents) which meanings can only be determined in the contexts they are used. The referents are analysed below.

\section{Extract 1}

Dinner tonight comes with gun wounds. Our desert

tongues lick the vegetable

blood-the pepper

strong enough to push scorpions

up our heads. Guests

look into the oceans of bowls

as vegetables die on their tongues.

Dinner, which is supposed to be a party of people assembled to have dinner together with fun and merriment, is used in conjunction with gun wounds which is a thing of pain. He compares the Sierra Leonean war to dinner and gun wounds as the meal. So, since it was a every terrible time for them, he calls when it happened tonight which means dark time. Such words (referents) refer to the fact that the battle in the dark time comes with a lot of injuries and devastations. He points out that what they expect from the dinner is gun wounds, and injured body filled with blood and heavy pains. The eating of dinner is also compared to the fighting of war, and the meal compared to gun wounds. The only element comparison here is that the two entails the gathering of people. War does not necessary happen in the night, but since night symbolizes darkness, dinner and war can be compared as they both happen in the dark times. The meal (gun wound) lies on their blood-drenched body (desert tongue) causing great pains.

The expressions, 'the pepper' and 'scorpions' explain the fact that the gun wounds cause a very terrible pain like that of a scorpion sting. The referent pepper which is a vegetable, is also compared to blood due to its red colour - an attribute it shares with the blood and the very fact that it creates pain, and that the flow of blood out of injury is accompanied with pain. The referent vegetable refers to human beings who are butchered like vegetables. The word, "tongue" in the same line also refers to human 
eyes. Here, the poet points out that their dry eyes is as red as pepper. Hence, the redness of their eyes is compared to the redness of pepper. The referent Guests refers to people who came to see the events of the war and gaze on the effects of the war and also felt the pains too. Thus, the poet uses referents such as dinner, tonight, gun wounds, desert tongues, vegetable blood, pepper, scorpions, guests, oceans of bowls, vegetables, and tongues to refer to the terrible incidents that happened during the war and the bad experiences of the citizenry.

\section{Extract 2}

\section{The table}

that gathers us is an island where guerillas

walk the land while crocodiles

surf. Children from Alphabetawith empty palms dine

with us; switchblades in their eyes,

silence in their voices. When the playground

is emptied of children`s toys

who needs roadblocks? When the hour

to drink from the cup of life ticks,

cholera breaks its spell on cracked lips

In extract 2 , the poet attempts to inform us that the table is actually an island which refers to Sierra Leone. The Guerrillas and crocodiles surf (select) children from Alphabeta (tender age, children who are still learning the alphabets) to join them in the fight. And these kids watch as people are slaughtered in their presence. The children have no option but to be silent and take what the day brings. Since the war has denied them the childhood privileges of playing with toys, let them play with guns then. The poet emphasizes destruction and pain through the referents especially the suffering of children who were used as fighters in the war and the sadness that creates silent in them as they see no reason to play since their play grounds are now battle grounds. This can also cause psychologically trauma for the children.

However, the poet makes reference to this aspect of the war in order to show the level the war got to and its deep effects on the leaders of tomorrow. The referents used in this stanza also show that there is no longer any kind of merriment in the land, for even the dying suffer cholera. The poet thus uses referents such as the table, an island, guerrillas, crocodiles, surf, Alphabeta, empty palms, switchblades, silence, voices, playground, children`s toys, roadblocks, cup of life, ticks, cracked lips to describe the situation during and after the war. 


\section{Extract 3}

Under the spilt

milk of the moon, I promise

to be a revolutionary, but my Nile, even

without tributaries comes lazy

upon its own Nile. On this

night reserved for lovers of fire, I'm

full with the catch of gun wounds, and my boots

have suddenly become too reluctant to walk me.

In extract 3 above, the poet affirms his stand on the war. He takes to be a revolutionary, which means, he will fight alongside those who fight to change the status quo. But, he also affirms that this war is meant for those who love violence. That he is tired of the injuries and destructions that the war brings, for even his boots no longer help him to walk again. He uses the flow of river Nile as a preamble to his retirement from the gun wounds dinner.

The poet does not resent the war for its cause, but for the destruction it brings to the land. Notice the first and second lines of the third stanza, 'under the spilt milk of the moon'. The use of night elements such as moon in the poem is to portray darkness - the time of war. The poet metaphorically refers to the rays of the moon as a spilt milk; he affirms that under any glimpse of light (this light might mean winning) in the war, he will remain a revolutionary. Then, he says, that even my Nile, the river Nile, without suffering anything gets tired of flowing as a river. That is to say he is not leaving the dinner of gun wounds for the lovers of fire because he is afraid, but, because he is tired of the inhumanity and destructions it bears; he is just tired of the war itself.

Indirectly, he tells us, never to continue a disastrous battle, even when we are winning and still have the strength to conquer. The harm war brings is more that the pride that comes with winning it. Even under the sense that they are winning the war, he chooses to stop the fight there to save the land first. This is sacrificial wisdom in display. He overlooks the pride of victory. Thus, with referents such as spilt milk, moon, revolutionary, Nile, tributaries, night, lovers of fire, gun wounds, boots, and walk, the poet was able to express his opinion on the civil war and his next line of action. 


\section{CONCLUSION}

The poet points accusing finger to the events of war and the troubles that come with it. This is evident with the deployment of the following referents in the poem: dinner, tonight, gun wounds, desert tongues, vegetable blood, pepper, scorpions, guests, oceans of bowls, vegetables, tongues, the table, an island, guerrillas, crocodiles, surf, Alphabeta, empty palms, switchblades, silence, voices, playground, children`s toys, roadblocks, cup of life, ticks, cracked lips, milk, moon, revolutionary, Nile, tributaries, night, lovers of fire, gun wounds, boots, walk. Since the situation surrounding the poem is that of war, the poet uses referents such as tonight to mean darkness, dinner to mean war and gun wounds to refer to food. Since war occurs in dark times and dinner is taken in the night, the poet uses the referent tonight to symbolize darkness. Also, in the poem, pepper and scorpion refer to pain; the table refers to Sierra Leone, and fire refers to destruction. These referents are used to express the brutality and horror of war, suffering, agony, revolution, the dark side of child soldiers, violence and blood bath. Thus, pragmatic reference helps to set the gloomy mood and sad tone of the poem.

\section{REFERENCES}

Aboh, R. and Uduk, H. (2016). The Pragmatics of Nigerian English in Chimamanda Ngozi Adichie's Novels. Journal of Language \& Education, 2(3), 6-13

Anne, B. and Schneider, K. P. (2009). Variational Pragmatics: Studying the impact of social factors on language use in interaction. Intercultural Pragmatics 6(4): 425-442.

Aremu, M. A. (2015). A Pragmatic Analysis of Nigerianisms in the English Usage in Soyinka's Death and the King's Horseman. The Journal of Pan African Studies, 8(5), 92-114.

Barbara, A. (2000). Presuppositions as nonassertions. Journal of Pragmatics, 32:1419 1437.

Birner, B. J., (2013). Introduction to Pragmatics, United Kingdom: Blackwell Publishing.

Emike, A. J. (2015). The Pragma-Crafting Theory: A Proposed Theoretical Framework for Pragmatic Analysis. American Research Journal of English and Literature, 1(2), 21-32

Garnham, A. and Cowles, H. W. (2006). Reference: Psycholinguistic Approach. Brighton, UK: Elsevier Ltd.

Gisle, A. and Karin, A. (eds.) (2011). Pragmatics of Society. Berlin/Boston: De Gruyter Mouton.

Grundy, P. (2000). Doing Pragmatics 2nd Ed. London: Arnold

Hidayat, A. (2016). Speech Acts: Force Behind Words. English Education: Jurnal Tadris Bahasa Inggris, 9(1), $1-12$.

Horn, L. R. \& Ward, G. (2006) The Handbook of Pragmatics. Oxford: Blackwell 
Idowu, O. (2005) "Pragma-Sociolinguistic Study of Names and Nicknames in Soyinka's Death and the King's Horseman" In Olateju, M \& Oyeleye I. (Eds) Perspectives on Language \& Literature. Ibadan: Obafemi Awolowo University Press.

Jegede, O. O. and Osoba, E. O. (2019). The Pragmatics of Proverbs in Ola Rotimi's Kurunmi. Bulletin of Advanced English Studies, 3(2), 92-100.

John, A. (2013). Saying x: The Pragmatics of a Nigerian Context. Studies in Literature and Language, 6(3), 39-44.

John, A. (2014). The Illocutionary Frames Principle (IFP) and the Austinian Postulations: A Clausestructure Investigative. Studies in Literature and Language, 7(1), 28-39.

Karin, A. (2013). Understanding Pragmatic Markers: A Variational Pragmatic Approach. Edinburgh: Edinburgh University Press.

Li, X. (2016). A Pragmatic Analysis of Humor Words in English Advertisements. English Language and Literature Studies, 6,(2), 193-201.

Mey, J. L., (2001). Pragmatics: An Introduction(2nd ed.). Oxford: Blackwell.

Odebunmi, A (2006). A Pragmatic Reading of Ahmed Yerima's Yemoja, Attairu \& Dry Leaves on Ukan Trees. Intercultural Pragmatics 3 (2), 153-169.

Odebunmi, A. (2008). Pragmatic Functions of Crisis - Motivated Proverbs in Ola Rotimi's the gods Are Not To Blame Linguistik on-line 33, 1/2008.

Sullivan, A. (2012). Referring in Discourse. In Allan, K and Jaszczolt, K. M. (eds), The Cambridge Handbook of Pragmatics. Cambridge: Cambridge University Press.

Susan, H., Stein, D. and Virtanen, T. (2013). Pragmatics of Computer-Mediated Communication. Berlin/Boston: De Gruyter Mouton.

Wangatiah, I. R. 1, Ongarora, D. \& Matu, P. (2016). Political Speeches and National Integration: A Pragmatic Analysis of selected Political Speeches in Kenya. Multilingual Academic Journal of Education and Social Sciences, 4(1), 66-76.

Yule, G. (2002). A Study of Language. Cambridge: Cambridge University Press. 